\title{
Identification and characterization of novel NF-kB dependent genes involved in HTLV-I pathogenesis
}

\author{
Zhaoxia Qu*, Gutian Xiao \\ From 17th International Conference on Human Retroviruses: HTLV and Related Viruses \\ Trois llets, Martinique. 18-21 June 2015
}

The NF-kB transcription factor plays pivotal roles in the pathogenesis and therapy-resistance of human cancers, including adult T-cell leukemia (ATL) induced by the oncoretrovirus HTLV-I. However, the downstream target genes of NF-kB involved in cancer biology and therapy remain largely unknown. To address this important issue, we have developed a novel approach called subtraction-based complementary gene expression cloning strategy. Given the characteristic anti-apoptosis activity of cancer cells, we used this approach to identify NFkB-dependent anti-apoptotic genes involved in HTLV-I oncogenesis. The principle of this strategy is that expression of anti-apoptotic genes induced by HTLV-Iactivated NF-kB should protect normal $\mathrm{T}$ cells from apoptosis induced by death inducers such as FasL. Briefly, a subtractive cDNA retroviral library enriched in genes induced by HTLV-I-NF-kB was generated and used to infect FasL-sensitive $\mathrm{T}$ cells. The infected $\mathrm{T}$ cells were treated with FasL and G418 (selective marker of cDNA expression). The FasL-and G418-resistant clones were isolated by limiting dilution, and the functional genes involved in FasL-resistance were fished out by RT-PCR and DNA sequencing. Using this strategy, several known NF-kB-dependent apoptotic genes have been identified, such as IAP1, Bcl-xL, c-FLIP and DcR2, indicating the reliability of our approach. Notably, numerous novel NF-kB-dependent anti-apoptotic genes were also identified. One of these novel genes has been confirmed to be expressed highly in HTLV-I-transformed $\mathrm{T}$ cells and primary ATL cells, and can be induced in normal T cells by HTLV-I in an NF-kBdependent manner. Our mechanistic studies further indicate that this novel protein binds to mitochondria and prevents FasL activation of Bid, Caspase 9 and

University of Pittsburgh Cancer Institute, Department of Microbiology and Molecular Genetics, University of Pittsburgh School of Medicine, Pittsburgh, PA, USA

C Biomed Central

(C) 2015 Qu and Xiao This is an Open Access article distributed under the terms of the Creative Commons Attribution License (http:// creativecommons.org/licenses/by/4.0), which permits unrestricted use, distribution, and reproduction in any medium, provided the original work is properly cited. The Creative Commons Public Domain Dedication waiver (http://creativecommons.org/publicdomain/ zero/1.0//) applies to the data made available in this article, unless otherwise stated.
Caspase 3 but not Caspase 8. Currently, we are actively investigating the pathophysiological role of this novel gene in the biology and therapy of ATL and other cancers associated with deregulated NF-kB.

Published: 28 August 2015

doi:10.1186/1742-4690-12-S1-P93

Cite this article as: Qu and Xiao: Identification and characterization of novel NF-kB dependent genes involved in HTLV-I pathogenesis. Retrovirology 2015 12(Suppl 1):P93.

Submit your next manuscript to BioMed Central and take full advantage of:

- Convenient online submission

- Thorough peer review

- No space constraints or color figure charges

- Immediate publication on acceptance

- Inclusion in PubMed, CAS, Scopus and Google Scholar

- Research which is freely available for redistribution Submit your manuscript at
www.biomedcentral.com/submit C Biomed Central 